\title{
Palynology of Jurassic (Bathonian) sediments from Donbas, northeast Ukraine
}

\author{
Olena Shevchuk $^{1}$ - Sam M. Slater ${ }^{2}$ - Vivi Vajda ${ }^{2}$ (D)
}

Received: 11 July 2017 / Revised: 14 September 2017 / Accepted: 26 October 2017 /Published online: 20 January 2018

(C) The Author(s) 2018. This article is an open access publication

\begin{abstract}
A palynological and sedimentological study of an outcrop succession adjacent to the village of Kamyanka within the Kharkiv region of northeast Ukraine was carried out. The successions occur within the Dnieper-Donets Basin, which hosts vast successions $(>20 \mathrm{~km}$ ) of post midDevonian strata and is one of the main hydrocarbonproducing basins in Europe. Middle Jurassic sandstones, siltstones and claystones represent the sedimentary successions at the Kamyanska locality. Few palynological studies have been performed on the Jurassic of Ukraine and even fewer presented in the international literature. Thirty spore taxa and 21 pollen taxa were identified, together with taxa kept in open nomenclature (e.g. bisaccate pollen). Two palynological assemblages were identified within the Kamyanska succession (assemblages A and B) dated as Bathonian. Assemblage A is dominated by the fern spores (Cyathidites and Osmundacidites) and gymnosperm pollen produced by Cupressaceae (Perinopollenites elatoides), ginkgophytes/Cycadales/ Bennettitales (monosulcates) and Cheirolepidiaceae (Classopollis). Assemblage B differs in also comprising high
\end{abstract}

This article is a contribution to the special issue "Jurassic biodiversity and terrestrial environments".

Vivi Vajda

vivi.vajda@nrm.se

Olena Shevchuk

hshevchuk@ukr.net

Sam M. Slater

sam.slater@nrm.se

1 Institute of Geological Sciences, National Academy of Sciences of Ukraine, Kyiv, Ukraine

2 Department of Palaeobiology, Swedish Museum of Natural History, 10418 Stockholm, Sweden abundances of Gleicheniidites and higher percentages of Pinuspollenites and Araucariacites compared to assemblage A. Another difference between the two units is the high relative abundance of seed fern pollen (Alisporites) in the upper part of assemblage B. The thermal alteration index (TAI) of the palynomorphs is estimated to range from 3 to 3.5 , indicating a burial depth corresponding to the mature main phase of liquid petroleum and, to some extent, gas generation. Comparisons between the miospore and macrofloral assemblages show that the palynoflora and macroflora are strongly similar at broad taxonomic levels. Importantly, the miospore assemblages described here compare well with European Middle Jurassic assemblages indicating limited provincialism, with similar vegetation extending from eastern Ukraine and across most of Western Europe.

Keywords Mesozoic - Kamyanka · Petroleum - Vegetation · Thermal alteration index (TAI) $\cdot$ Dnieper-Donets Basin

\section{Introduction}

The Jurassic is an interesting period in the Earth's history as it saw the rise to ecological dominance of the dinosaurs, the evolution of birds, extant sub-classes of mammals, the fragmentation of Pangea and two major flood basalt events, both associated with massive biotic change. This took place in a context of generally elevated $\mathrm{CO}_{2}$ and muted latitudinal temperature gradients; i.e. temperature differences between the tropics and the polar regions were less extreme compared to the present (Steinthorsdottir and Vajda 2015; Slater et al. 2018a, this issue). The poles were ice-free, and the vegetation was characterised by little provincialism (Vajda and WigforssLange 2009). However, in order to compare and contrast the vegetation between different regions through the palynoflora, 
Fig. 1 Location of the DnieperDonets-Donbas Basin and the sample location (marked with red triangle), modified after Kabyshev et al. (1998)

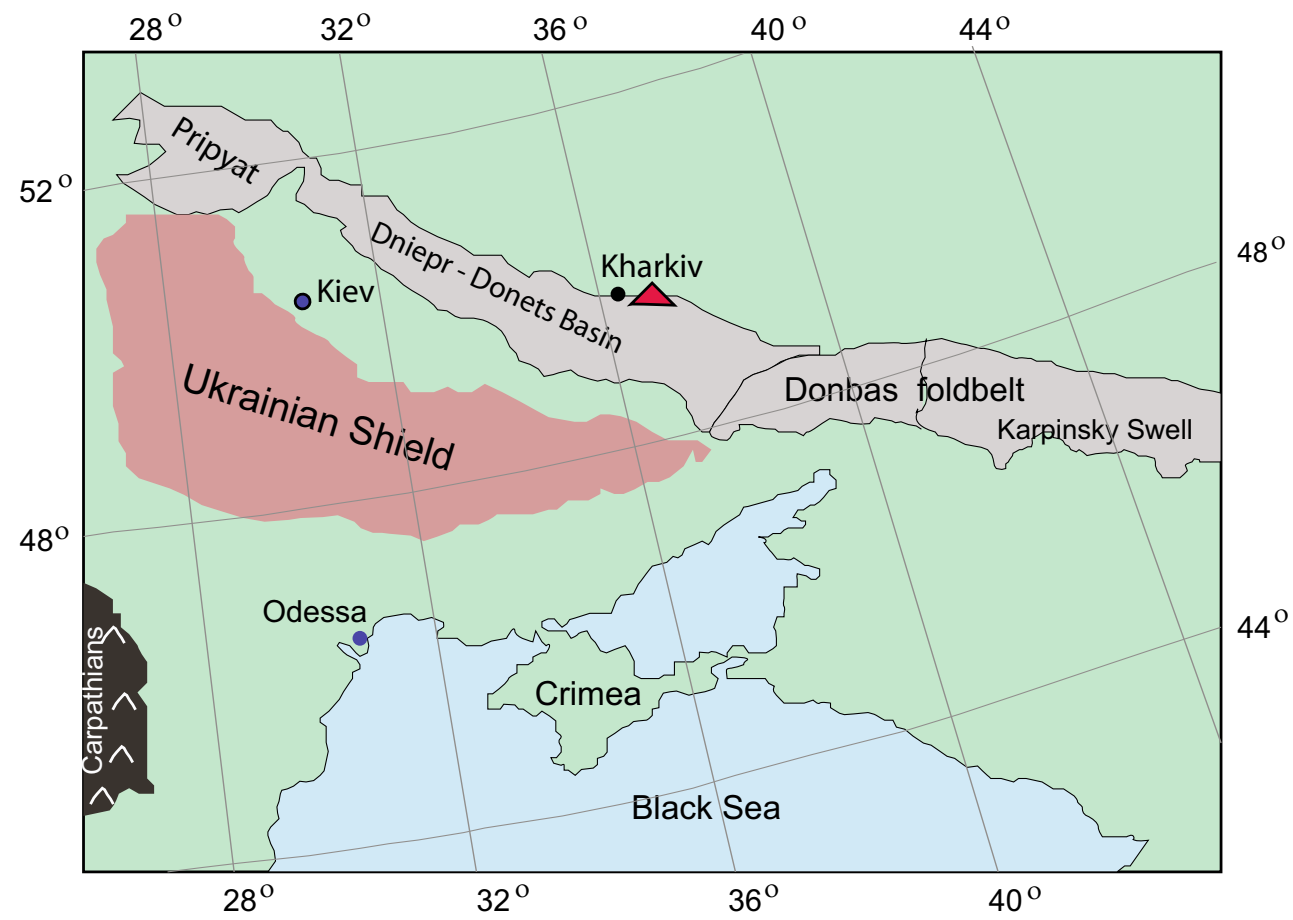

Palynological studies of Jurassic deposits of the DnieperDonets and the Donbas depressions have previously been conducted by Shramkova (1963, 1970) and Yanovskaya (1986). Lapteva (1967) described the miospore assemblages from drill core successions from northwestern Donbas and dated these as Jurassic (Toarcian-Bajocian), while Semenova (1970) documented palynofloras from successions spanning the Triassic-Jurassic boundary. However, the successions

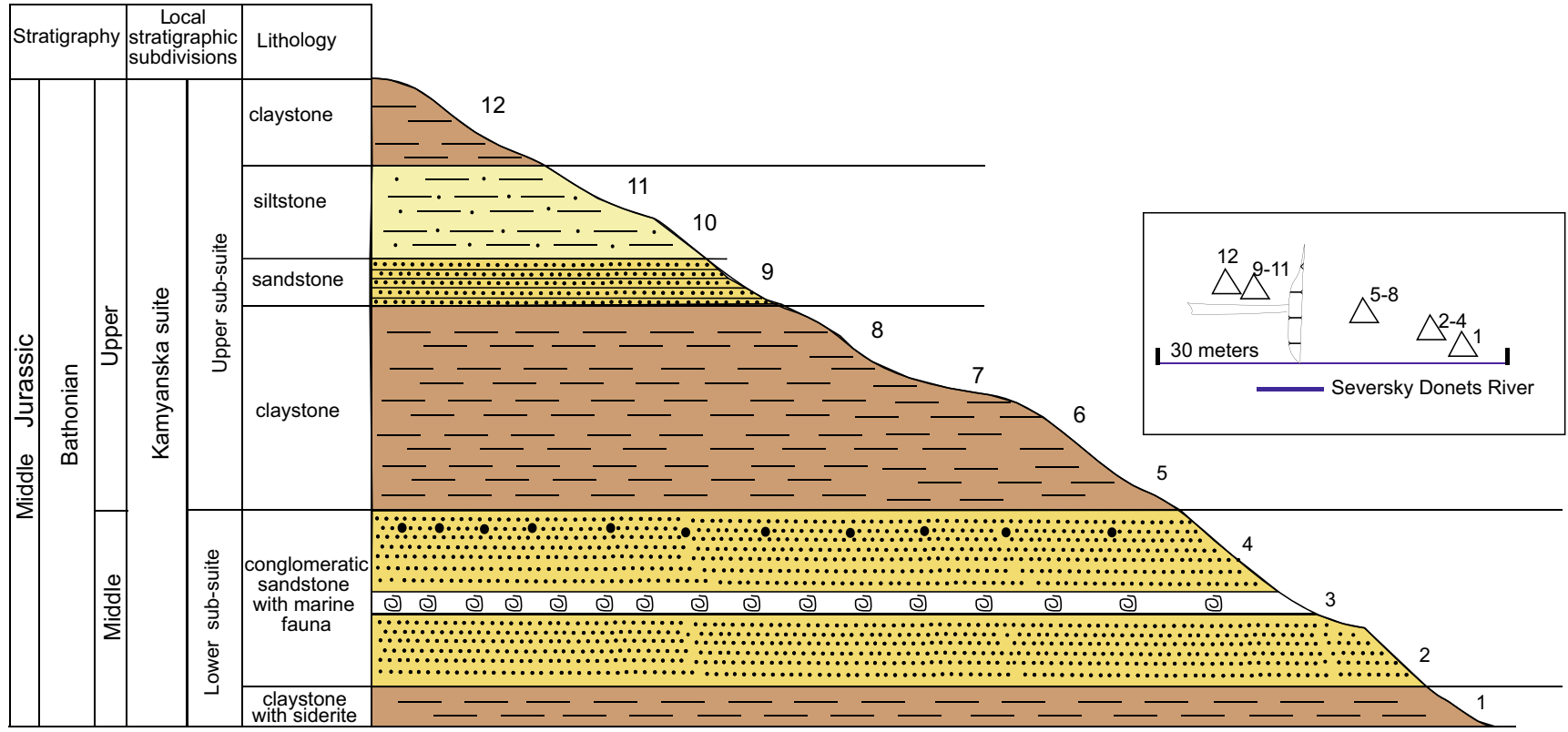

Fig. 2 Composite section of the studied Kamyanski outcrops. The location of palynological sample numbers 1-12 is indicated. Samples from the lower sub-suite are assigned to palynological assemblage $\mathrm{A}$ and those from the upper sub-suite to palynological assemblage $\mathrm{B}$ 

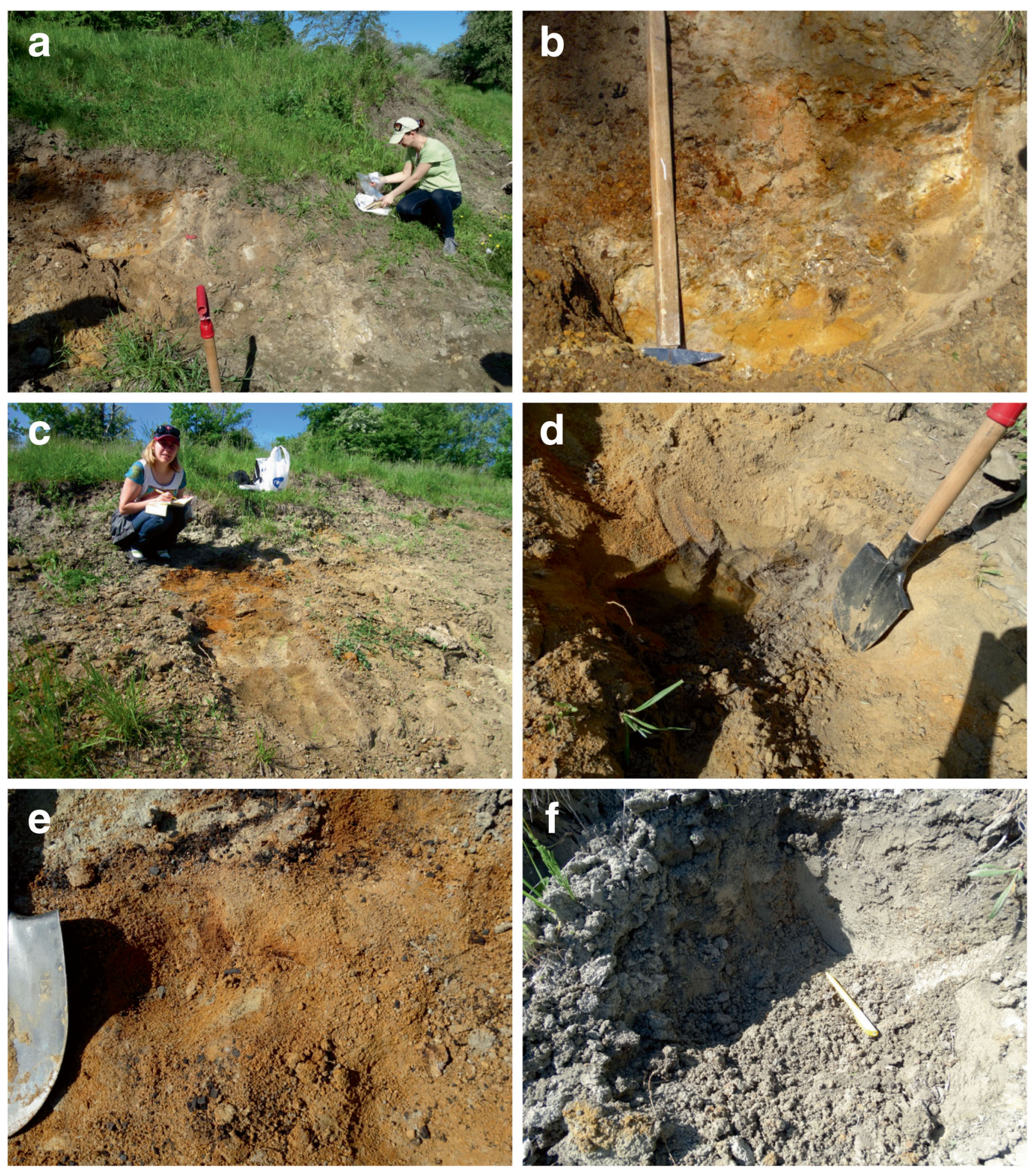

Fig. 3 Photographs of the sampled successions at Kamyanka. For site location, see Fig. 2. a Sampling locality 1, samples 2-4, conglomeratic sandstone with marine fauna. b Sampling locality 2, sample 1, claystone

exposed close to the village of Kamyanka have so far not been studied palynologically although the locality hosts some important macrofloral assemblages (Stanislavskyi 1957a and references therein). with siderite. c-e Sampling locality 3, samples 5-8, claystone. f Sampling locality 5, samples 9-11, siltstones

The study of the Kamyanska palynoflora is important for detailed palaeoenvironmental interpretations and for resolving the position of the Bathonian and Callovian boundary within the Dnieper-Donets depression and Donbas. The main aim of 
Table 1 Relative abundance data expressed in percentages for samples 1-12 from the Kamyanska succession

\begin{tabular}{|c|c|c|c|c|c|c|c|c|c|c|c|c|}
\hline Sample number & 1 & 2 & 3 & 4 & 5 & 6 & 7 & 8 & 9 & 10 & 11 & 12 \\
\hline Height (m) from base of section & 0 & 1 & 2 & 3 & 4 & 5 & 6 & 7 & 8 & 8.5 & 9 & 11 \\
\hline \multicolumn{13}{|l|}{ Bryophyta (Mosses) } \\
\hline Foraminisporis spp. & 0.4 & & 0.3 & 0.1 & & & & & 0.8 & & 0.3 & \\
\hline Stereisporites spp. & 1.3 & 1.2 & 0.3 & 0.7 & 0.3 & 0.3 & 0.5 & 0.3 & 2.1 & 2.2 & 0.3 & 1.0 \\
\hline Bryophytes total & 1.7 & 1.2 & 0.6 & 0.8 & 0.3 & 0.3 & 0.5 & 0.3 & 2.9 & 2.2 & 0.5 & 1.0 \\
\hline \multicolumn{13}{|l|}{ Lycopsida (club mosses) } \\
\hline Acanthotriletes spp. & 0.1 & & & 0.3 & & & & & & & & \\
\hline Densoisporites velatus & 0.5 & & 1.2 & 0.7 & & 0.6 & 0.5 & 0.2 & 0.2 & & 0.3 & \\
\hline Foveosporites pseudoalveolatus & 0.2 & & & 0.1 & 0.3 & 0.3 & & 0.2 & & & & \\
\hline Leptolepidites spp. & 0.4 & 1.2 & 0.3 & 0.1 & 0.3 & 0.3 & 0.5 & 0.2 & 1.5 & & 0.7 & 5.2 \\
\hline Neoraistrickia gristhorpensis & 1.1 & & & 0.3 & 0.3 & 0.3 & 0.5 & 0.5 & 0.6 & & & 3.6 \\
\hline Retitriletes spp. & 0.5 & & 0.8 & 0.6 & 0.5 & 0.4 & 1.4 & 0.3 & 0.2 & 2.2 & 0.3 & 3.0 \\
\hline Retitriletes austroclavatidites & & & & & & 0.3 & & 0.2 & 0.3 & & 0.3 & 0.5 \\
\hline Retitriletes marginatus & & & & 0.3 & 0.5 & & & & & & & \\
\hline Lycopsida total & 2.9 & 1.2 & 2.3 & 2.4 & 2.8 & 2.0 & 2.7 & 1.4 & 2.7 & 2.2 & 1.5 & 12.3 \\
\hline \multicolumn{13}{|l|}{ Sphenophyta } \\
\hline Calamospora mesozoica & 0.2 & 1.2 & 0.3 & 0.1 & & & 0.5 & 0.5 & 1.4 & & 2.1 & \\
\hline Equisetites spp. & & & & 0.1 & 0.3 & & & & & & & \\
\hline Sphenophyta total & 0.2 & 1.2 & 0.3 & 0.2 & 0.3 & & 0.5 & 0.5 & 1.4 & & 2.1 & \\
\hline \multicolumn{13}{|l|}{ Filicopsida (Ferns) } \\
\hline Cibotiumspora jurienensis & 1.3 & 2.3 & 0.5 & 0.7 & & 1.1 & 3.2 & 0.8 & & & 0.9 & 0.5 \\
\hline Cyathidites spp. & 31.6 & 14.8 & 21.4 & 34.3 & 26.1 & 23.2 & 16.9 & 21.0 & 15.0 & 13.1 & 6.5 & 14.1 \\
\hline Deltoidospora toralis & 2.3 & 2.3 & 1.2 & 2.3 & 1.0 & 2.2 & 0.5 & 6.0 & 2.3 & & 0.3 & 1.0 \\
\hline Glecheniidites spp. & 3.2 & 2.4 & 0.3 & 1.0 & 2.3 & 2.2 & 2.7 & 5.4 & 1.5 & 2.2 & 0.5 & 9.2 \\
\hline Hymenophyllum sp. & 0.2 & & 0.3 & 0.3 & & & & 1.1 & 0.5 & & 1.2 & 1.9 \\
\hline Klukisporites variegatus & 1.4 & 2.3 & 2.5 & 5.5 & 0.8 & 1.1 & 1.4 & 4.4 & 0.8 & 2.2 & & 1.3 \\
\hline Leiotriletes sp. & 0.9 & 1.2 & 1.4 & 0.9 & 1.8 & 2.7 & 5.9 & 2.0 & 3.1 & & 0.9 & 1.1 \\
\hline Lophotriletes sp. & & & & & & & & & & & & 1.9 \\
\hline Marattisporites scabratus & 3.1 & 4.5 & 1.9 & 0.9 & 4.4 & 5.1 & 3.2 & 2.1 & 4.1 & 2.2 & 2.5 & 2.4 \\
\hline Matoniasporites spp. & & & 0.6 & 1.3 & 0.5 & 0.3 & & 0.2 & 0.3 & 2.2 & 1.2 & \\
\hline Osmundacidites spp. & 9.4 & 11.5 & 5.4 & 6.5 & 6.2 & 9.4 & 6.8 & 8.6 & 9.3 & 2.2 & 6.8 & 1.7 \\
\hline Polypodisporites jurassicus & & & 0.3 & & & & & & & & & \\
\hline Pteridium solidum & & & & 0.3 & & & & & & & & \\
\hline Striatella seebergensis & 0.9 & & & 0.5 & & & 0.5 & & 0.2 & & 0.7 & 0.5 \\
\hline Todisporites spp. & 2.6 & & 1.1 & 1.1 & 0.8 & 0.3 & 1.8 & 3.7 & 3.1 & 2.2 & 1.9 & 0.5 \\
\hline Trilobosporites subsimplex & & & & & 1.3 & & & & 0.5 & & 0.7 & \\
\hline Tripartina variabilis & 0.6 & & 1.2 & 1.7 & & 0.3 & 0.9 & 0.2 & 0.5 & & & \\
\hline Trilete spore spp. & 0.2 & & & 0.1 & & & & & 0.3 & & & \\
\hline Filicopsida total & 57.7 & 41.2 & 38.1 & 57.4 & 45.2 & 47.6 & 43.8 & 55.4 & 41.2 & 26.4 & 24.0 & 36.2 \\
\hline \multicolumn{13}{|l|}{ Gymnosperma } \\
\hline Alisporites spp. & & & 1.1 & 0.6 & 2.6 & 2.9 & 0.5 & 0.8 & 0.2 & & 4.6 & \\
\hline Araucariacites australis & 3.1 & 1.2 & 6.3 & 2.1 & 4.7 & 4.4 & 3.2 & 2.9 & 3.2 & 8.7 & 5.2 & 3.7 \\
\hline Brachyphyllum sp. & 0.1 & & & & & & & 0.1 & 0.6 & 2.2 & 0.3 & 0.5 \\
\hline Callialasporites spp. & 0.8 & & 0.5 & 0.2 & & & & 0.2 & 0.2 & & & \\
\hline Callialasporites dampieri & & & & & 0.5 & 1.8 & 0.5 & & & & & \\
\hline Callialasporites segmentatus & & & & & & 0.5 & & 0.5 & & & & \\
\hline Callialasporites trilobatus & 0.1 & & & & & 0.3 & & & 0.3 & & 0.3 & \\
\hline
\end{tabular}


Table 1 (continued)

\begin{tabular}{|c|c|c|c|c|c|c|c|c|c|c|c|c|}
\hline Sample number & 1 & 2 & 3 & 4 & 5 & 6 & 7 & 8 & 9 & 10 & 11 & 12 \\
\hline Cerebropollenites macroverrucosus & 0.6 & & 0.8 & 0.4 & 1.0 & 0.6 & 0.9 & 0.8 & 0.5 & & & 0.6 \\
\hline Chasmatosporites apertus & 0.2 & & & 0.1 & 0.3 & 0.3 & & & & & & 0.2 \\
\hline Classopollis spp. & 2.1 & 9.2 & 4.6 & 0.9 & 1.8 & 2.4 & 2.3 & 0.9 & 1.2 & 6.5 & 4.9 & 1.3 \\
\hline Cupressaceae spp. & 5.4 & 13.7 & 20.3 & 2.0 & 3.4 & 5.4 & 5.9 & 2.6 & 4.3 & 6.5 & 25.6 & 1.1 \\
\hline Eucommiidites troedssonii & 1.3 & 4.5 & 0.3 & 0.8 & 3.4 & 8.1 & 5.0 & 2.3 & 0.3 & & 0.5 & 3.0 \\
\hline $\begin{array}{l}\text { Monosulcites spp. } \\
\text { (ginkgophytes/Cycadales/Bennettitales) }\end{array}$ & 5.0 & 5.7 & 7.0 & 4.9 & 4.9 & 6.3 & 8.2 & 7.7 & 6.1 & 10.7 & 6.5 & 4.4 \\
\hline Inaperturopollenites spp. & 3.7 & 6.9 & 5.3 & 7.0 & 7.9 & 5.1 & 8.7 & 5.8 & 6.9 & 8.7 & 12.7 & 2.4 \\
\hline Perinopollenites elatoides & 0.4 & 1.2 & & 0.2 & 5.2 & 2.0 & 4.6 & 2.0 & 4.0 & & 1.9 & 1.6 \\
\hline Piceapollenites spp. & 7.8 & 1.2 & 7.9 & 12.7 & 5.0 & 3.8 & 2.7 & 4.6 & 10.7 & 15.2 & 3.3 & 3.1 \\
\hline Pinuspollenites spp. & & & & 1.3 & 9.2 & 4.3 & 7.3 & 7.1 & 2.1 & 10.7 & 0.9 & 26.2 \\
\hline Podocarpidites spp. & 0.5 & & & 0.3 & & 0.4 & & & 0.3 & & & \\
\hline Quadraeculina annelaeformis & 0.1 & & 0.3 & & & & 0.9 & & & & & \\
\hline Spheripollenites psilatus & & & & & & & & 0.2 & 0.5 & & & \\
\hline Vitreisporites pallidus & 0.9 & & 0.8 & 0.5 & & & 0.5 & 0.9 & 2.0 & & 0.9 & 1.8 \\
\hline Bisaccates spp. & 5.3 & & 3.6 & 5.0 & 1.7 & 1.4 & 1.4 & 3.2 & 8.5 & & 4.2 & 0.5 \\
\hline Gymnosperma total & 37.4 & 43.7 & 58.7 & 39.2 & 51.4 & 50.0 & 52.5 & 42.5 & 51.8 & 69.2 & 71.9 & 50.6 \\
\hline Sp. Indet. & & 11.5 & & & & & & & & & & \\
\hline Total \% & 100 & 100 & 100 & 100 & 100 & 100 & 100 & 100 & 100 & 100 & 100 & 100 \\
\hline
\end{tabular}

Total values are presented in bold

this study is to describe the palynoflora from this palynologically previously unstudied site along the Donets River, using an integrative approach based on the collaboration between eastern and western palynologists, to assess the age and the ecological context of the alternating marine and continental Kamyanska suite and to compare the miospore assemblages with the macroflora.

\section{Geological setting}

The Dnieper-Donets Basin is located between the Ukrainian Shield to the south and the Voronezh Massif to the north, in the southwest part of the East European Craton (Fig. 1). The basin represents a deep intra-cratonic rift with up to $22 \mathrm{~km}$ of sediments spanning the mid-Devonian-Cenozoic and
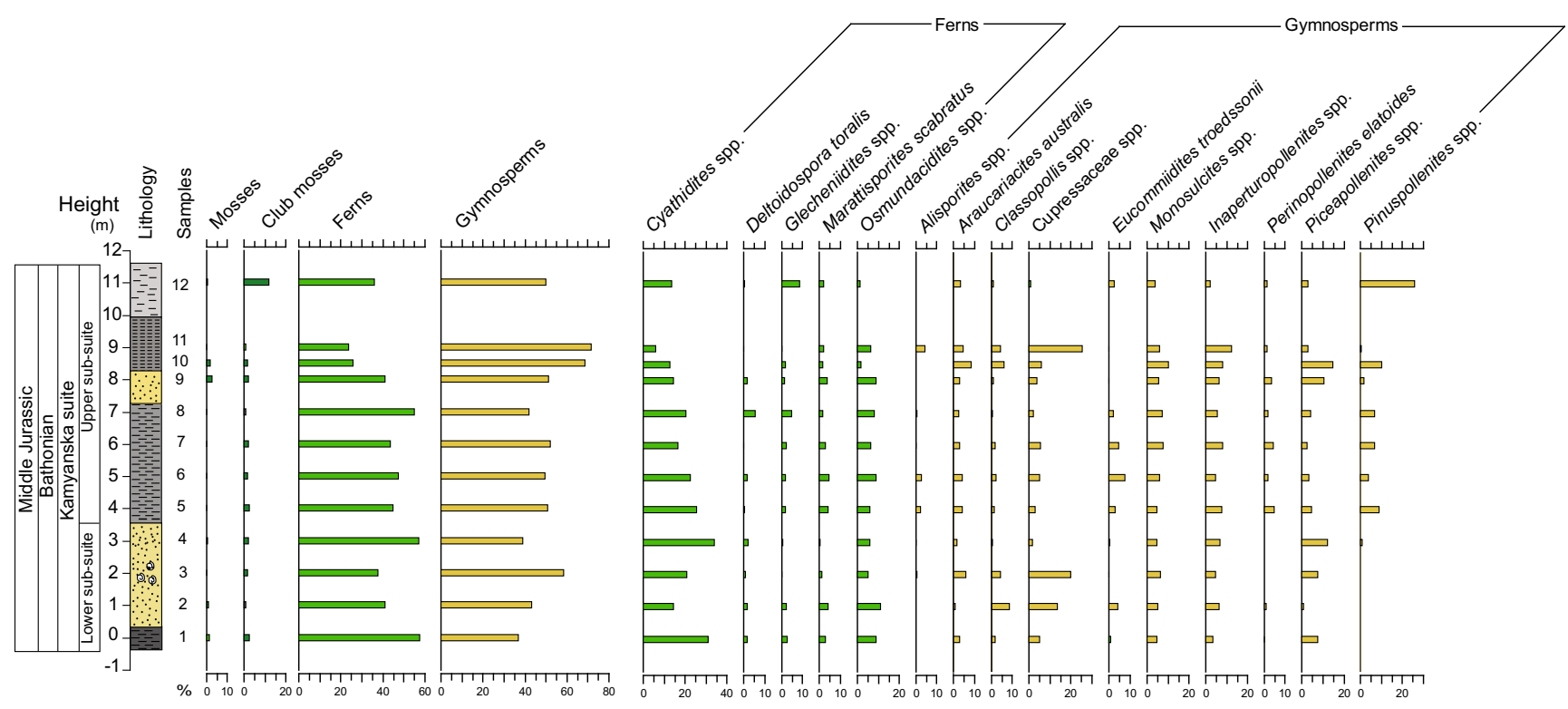

Fig. 4 Relative abundances (percentages) of selected pollen and spore taxa from the studied Bathonian succession at Kamyanka, Ukraine. Left in diagram, percentage of major plant groups based on the affinity of the identified spores and pollen 
is characterised by a WNW-ESE trending axis (Lungershausen 1942; Stovba et al. 2003; Sachsenhofer et al. 2012). The sedimentary successions within the basin are poorly exposed, and knowledge about the sedimentary evolution is derived mainly from sub-surface data. However, the eastern part of the basin was inverted to various degrees during the early Permian, at the end-Triassic, end-Jurassic and end-Cretaceous (Kabyshev et al. 1998; Stovba et al. 2003). These tectonic events formed the Donbas Foldbelt, where exposures occur. Strata are also exposed at some sites along the margin of the basin.

The Dnieper-Donets Basin hosts one of the main hydrocarbon and coal resources in Europe (Aliev et al. 1981; Kabyshev et al. 1998) of which the major portion is contained in Carboniferous to Permian successions deposited during the post-rift pre-inversion stage of the basin evolution (Kabyshev et al. 1998). Additional oil and gas accumulations are hosted within the Triassic and Jurassic post-inversion series.

The studied section is administratively located in the Kharkiv region of Ukraine, at the boundary between the northwest Donbas and Dnieper-Donets depressions, and is part of the East European Platform (Fig. 1; Stanislavskyi 1957a, b, 1965). The deposits of the Kamyanska suite have been dated as Middle Jurassic (Bathonian) based on the macroflora (Stanislavskyi 1957a, 1964 and references therein) and invertebrates (Gozhik 2013). Bathonian deposits are known throughout the studied region and are here represented by a variety of lithologies. The local stratigraphic unit is known as the Kamyanska suite, named by Lungershausen (1942) after the nearby village of Kamyanka in the Kharkiv region (Fig. 1) [Note that we follow the Ukrainian grammar when discussing the site locality, where the adjective form of Kamyanka is Kamyanska (singularis) or Kamyanski (pluralis), e.g. the village of Kamyanka, but Kamyanska flora/Kamyanski floras]. The succession is divided into two sub-suites (Fig. 2). The basal one is represented by tuffaceous sandstones alternating with mudstones and limestones and reaches a thickness of c. $100 \mathrm{~m}$. Molluscs representing the lower Bathonian Pseudocosmoceras michalskii zone have been found within the lower part of the tuffaceous sandstones including Meleagrinella doneziana (Boriis), Gocoma (?) carinata Goldf., Ferganoconcha schabarovi Tchern., Ferganoconcha sibirica Tchern. and Lingula sterlini Macrid. (Gozhik 2013).

Plant fragments are common in the sandstones within the lower Kamyanska sub-suite, particularly ferns (mostly Coniopteris hymenophylloides (Brongniart) Seward and ginkgophytes (Stanislavskyi 1953, 1957a, b). These cooccur with shells of Pseudomonotis and the bivalve Ferganoconcha. Brittle stars, small bivalves (Spondylus) and other fossils are present in the clay lenses. These sandstones were mainly deposited under marine conditions. The upper part of the tuffaceous sandstones are intercalated with
Fig. 5 Representative spores from the studied succession, followed by the sample number in brackets. Scale bar $=10 \mu \mathrm{m}$. a Cyathidites australis Couper (1). b Cibotiumspora jurienensis (Balme) Filatoff (1). c Deltoidospora toralis Lund (1). d Osmundacidites tuberculatus (Klimko) Semenova (1). e Neoraistrickia gristhorpensis (Couper) Tralau f Cibotiumspora jurienensis (1). g-h Striatella seebergensis Mädler (1). i Marattisporites scabratus Couper (1). j-k Todisporites spp. $(1,1)$. I Stereisporites spp. (1). m Klukisporites variegatus Couper (1). n Retitriletes spp. (2). o Densoisporites velatus Weyland et Krieger emend. Krasnova. (1). p Calamospora mesozoica Couper (3). q Uvaesporites sp. (2)

ironstone beds hosting horsetails, and clay beds with leaves of Cladophlebis crenata Font.

Along the Sukha Kamyanka River, the tributary river to the Donets River, the pattern is somewhat different as the sandstone successions host a macroflora represented by taxa such as Neocalamites spp., Sagenopteris spp., Nilssonia orientalis Heer, Gingko digitata (Brongn.) Heer, Ginkgodium nathorstii Jok., Elatides setosa (Phill.) Sew. and Elatides curvifolia (Dunker) Nath. (Stanislavskyi 1957a and references therein). These co-occur with plants also present in the lower part of the mudstone succession at Kamyanka, outlined above. Within the topmost part of the basal suite, clay and coal lenses of continental origin are encountered, reflecting a non-marine setting (Fig. 2).

The topmost sub-suite reaches a thickness of c. $15 \mathrm{~m}$ and comprises silty claystones intercalated with sandstone beds and coal lenses. This sub-suite is rich in plant fossils, the socalled Kamyanska flora, which has been extensively studied, mainly in river valleys along the Sukha Kamyanka River and other tributaries of the Donets River (Figs. 1 and 3). The plant remains are best preserved in lenses of brown ironstone, while other lithologies are typically poorly cemented and brittle; thus, macrofossils in other lithologies are highly fragmentary.

The oldest published record of the flora is by Eichwald (1865), followed by Grigoryev (1900); Thomas (1911); Kryshtofovich (1917) and Kryshtofovich and Prinada (1934). Their work was followed by Stanislavskyi (1953, 1957a, b, 1964, 1965), who dated the flora as Bathonian Stanislavskyi (1957b). However, in the topmost portion of the Kamyanska suite, the diversity of the macroflora is considerably lower and, it has tentatively been suggested that the upper part of the succession is of an early Callovian age (Yamnichenko 1969).

The topmost part of the Kamyanska suite is probably entirely non-marine, also reflected in the abundant palaeosols with in situ roots and in the thick lenses containing roots of horsetails alternating with lenses containing fossilised leaves. The macroflora is sparser in the upper part of the mudstone succession, mainly owing to the lower abundance and diversity of cycadophytes, ginkgophytes and ferns (Stanislavskyi 1957a and references therein). 

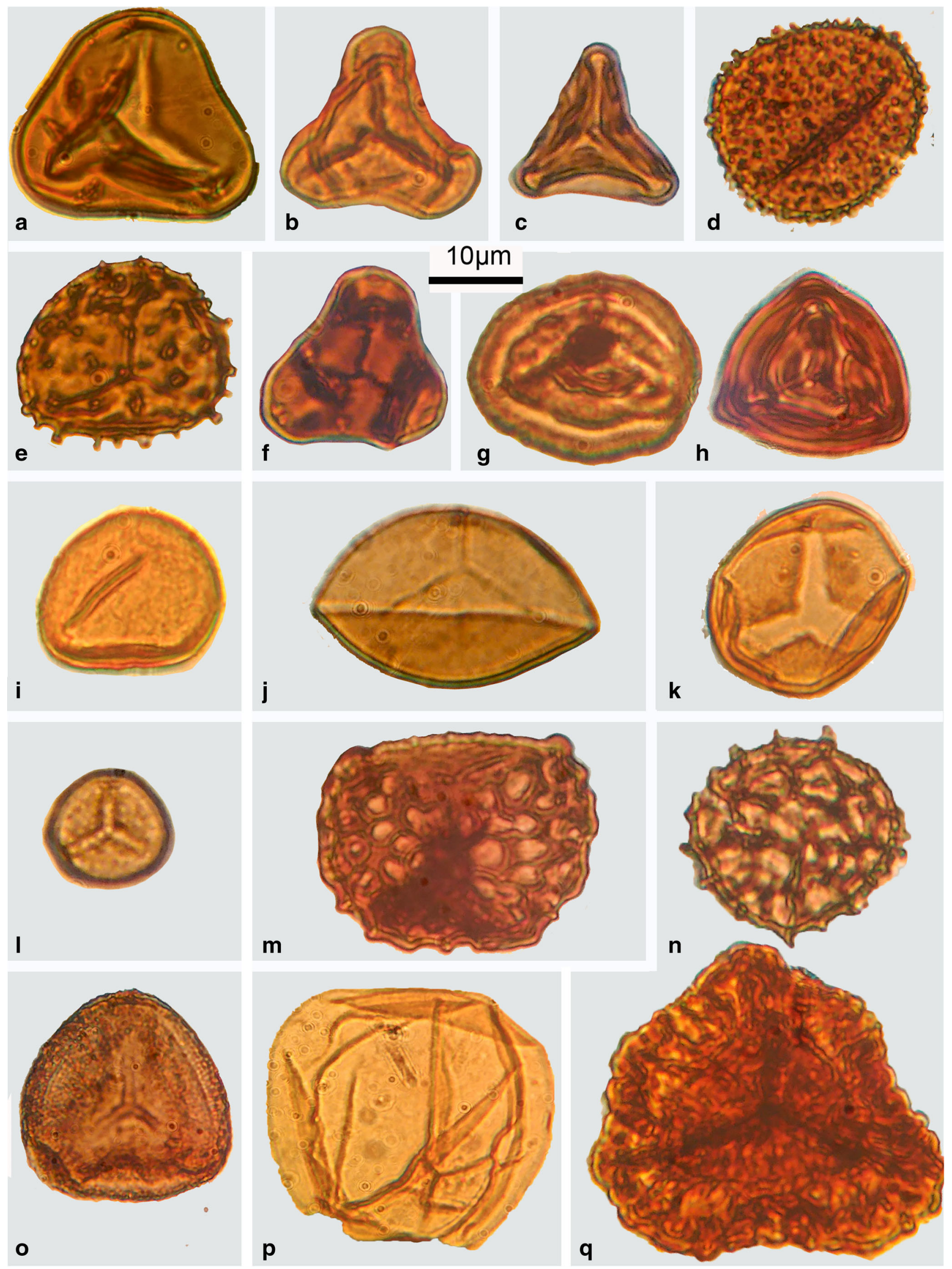


\section{Material and methods}

Twelve samples were collected for palynological analysis from a locality east of the village of Kamyanka from a series of outcrops along the western bank of the Donets River (Fig. 3). This section is the stratotype for the Kamyanska suite and is valid for the entire Dnieper-Donets depression and northwestern Donbas. Around $20 \mathrm{~g}$ of sedimentary rock was processed according to standard palynological procedures at Global Geolab Limited. The organic residue was sieved using a $5 \mu \mathrm{m}$ mesh and mounted in epoxy resin on two microscope slides. All pollen and spores in the two slides were identified, and the percentage of each palynomorph taxon was calculated (Table 1, Fig. 4). Additionally, one kerogen slide was prepared from each sample (i.e. where the residue was not exposed to oxidation or sieving processes) in order to estimate the thermal alteration index (TAI) of the palynomorphs.

The slides and residues are hosted in the palaeobiology collections of the Department of Stratigraphy and Paleontology at the Institute of Geological Sciences of the National Academy of Sciences, Kyiv, Ukraine.

\section{Palynological results}

Well-preserved palynological assemblages were recovered from all 12 samples, and selected pollen and spores are illustrated in Figs. 5 and 6. Based on the occurrence of taxa and quantitative representation of the different miospore groups, two assemblages were identified: assemblage A and assemblage B. Although Middle Jurassic palynofloras do not permit a detailed stratigraphic division (FeistBurkhardt 1992), assemblage A is dated as middle Bathonian based on the marine mollusc fauna present in the lower sub-suite. The overlying sub-suite, represented by our palynological assemblage $B$ is dated as late Bathonian (upper sub-suite) based on the macroflora. The thermal alteration index of the palynomorphs is estimated to range from 3 to 3.5 , indicating an interval within the mature main phase of liquid petroleum to wet gas generation (Batten 1996).

A total of 30 spore and 21 pollen taxa were identified with additional taxa in open nomenclature (e.g. bisaccate pollen group). Additionally, and outside counts, a few specimens of the freshwater algae Botryococcus were identified, along with a few dinoflagellate specimens and some insect remains. Where possible, we have applied the natural classification system, but combined with application of form taxa. We have also compared the palynological assemblages with the regional macrofloral record outlined in previous publications.
Assemblage A: samples 1-4, sub-suite 1

\section{Age: middle Bathonian}

The samples belonging to assemblage A all derive from the basal sub-suite at Kamyanka. The lithology varies between the samples collected from sub-suite 1 ; sample 1 is represented by sideritic mudstone while samples $2-4$ comprise sandstones or conglomeratic sandstone (Fig. 2). Here, 26 spore and 19 pollen taxa were identified. Spores dominate over gymnosperm pollen, making up c. $52 \%$, and are dominated by the genera Cyathidites and Osmundacidites. Bryophyte and lycophyte spores only make up very limited portions, not exceeding $2 \%$ in relative abundance.

Gymnosperm pollen reach an average of $45 \%$ within sub-suite 1, and pollen produced by Cupressaceae, ginkgophytes/Cycadales/Bennettitales (monosulcates) and Cheirolepidiaceae (Classopollis) dominate. Additional elements comprise fungal spores and hyphae. Based on the palynology and supported by the marine fauna, subsuite 1 is dated to middle Bathonian.

Assemblage B: samples 5-12, sub-suite 2

\section{Age: late Bathonian}

The samples belonging to assemblage $\mathrm{B}$ all derive from the upper sub-suite 2 at Kamyanka. The lithology of subsuite 2 comprises claystones in the base, and the topmost part, with a thinner unit of sandstones and siltstones between (Fig. 2). Here, 27 spore and 22 pollen taxa were identified. Within assemblage $\mathrm{B}$, pollen are more abundant than spores, reaching an average of $55 \%$, of which pollen produced by members of the family Cupressaceae dominate together with Pinus-pollenites and Araucariacites, which reach higher portions in assemblage B compared to assemblage A. Other differences within the gymnosperms between the two units are the high relative abundance of seed fern pollen (Alisporites) in the top of the succession of sub-suite 2 (assemblage B). Spores reach relative abundances of $45 \%$ in assemblage $\mathrm{B}$, and are highly dominated by fern spores (ranging from 24 to $55 \%$ ) and in particular by the genera Cyathidites, Osmundacidites and Gleicheniidites. Osmundacidites spores reduce in relative abundance at the topmost part of the succession, which is mirrored by an increase in lycophyte spores, which record their highest portions in the topmost sample. Assemblage B is dated as late Bathonian based on the macroflora and is supported by the palynology. 

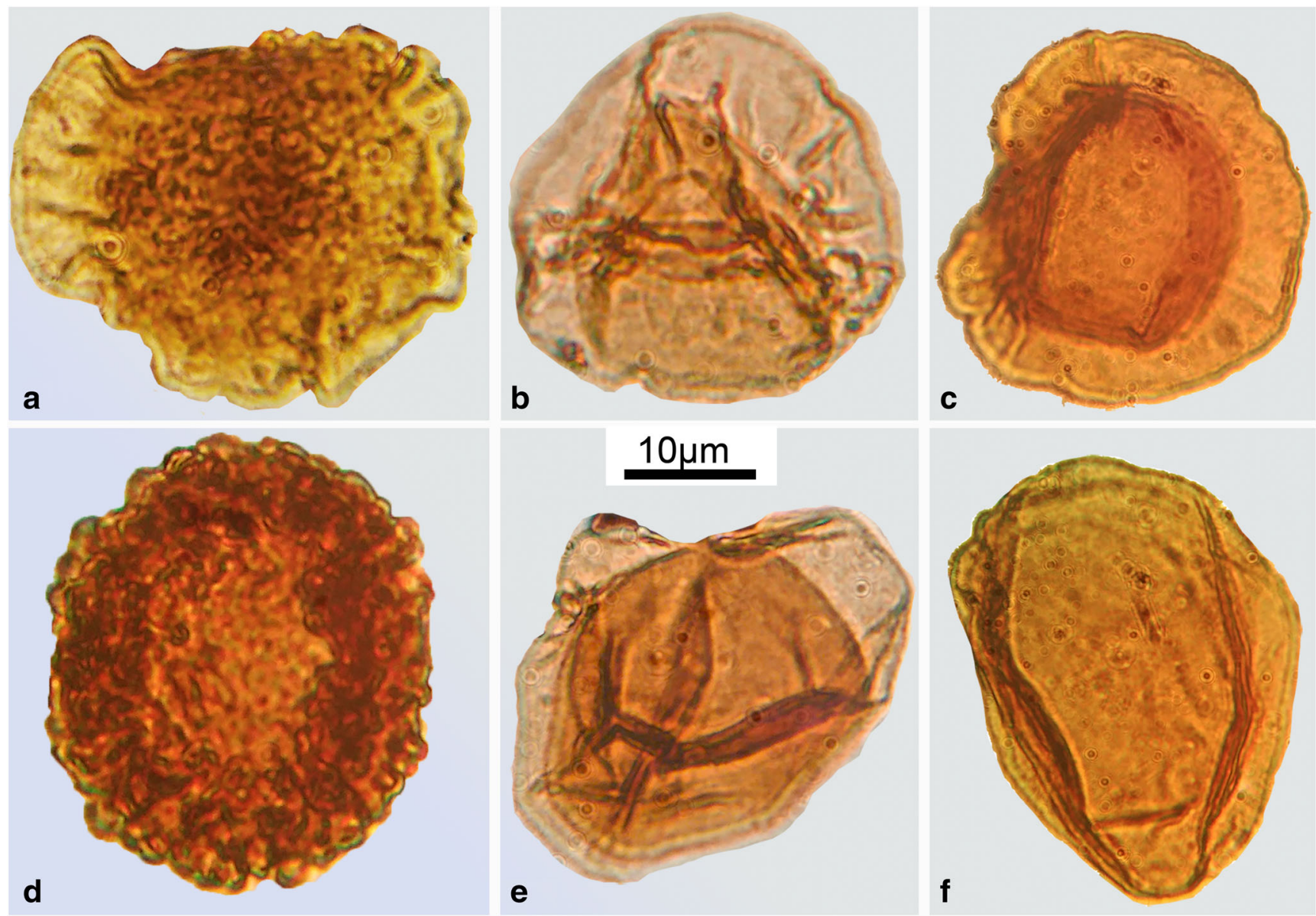

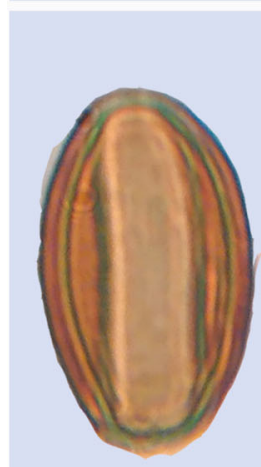

g
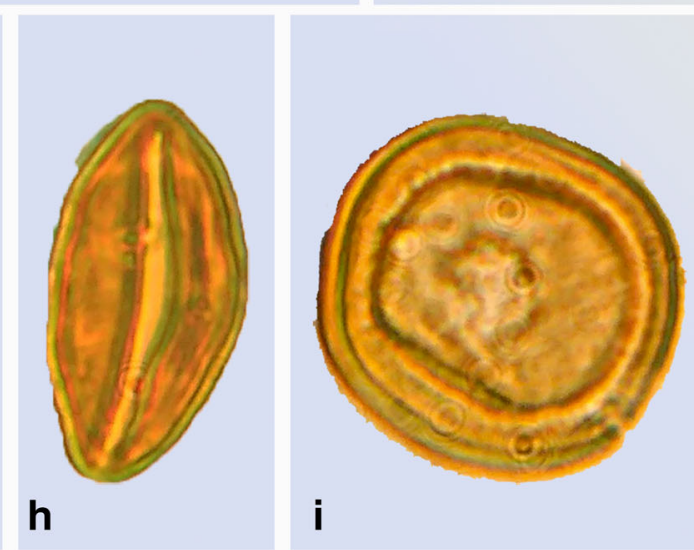

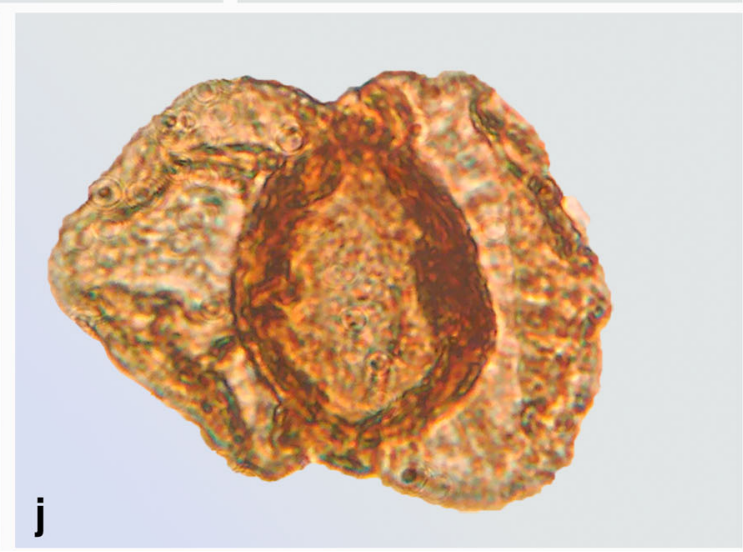

Fig. 6 Representative pollen grains from the studied succession, followed by the sample number in brackets. Scale bar $=10 \mu \mathrm{m}$. a Callialasporites sp. (1). b Callialasporites trilobatus (Balme) Dev. (1). c Callialasporites dampieri (Balme) Dev. (5).

\section{Comparison with other regional floras}

Bathonian successions of northwestern Donbas can be traced in both continental and marine facies within the DnieperDonets depression and along the eastern slope of the Ukrainian Shield (Ilyina 1968; Shevchuk 2007; Shevchuk and Vajda 2016). Fern spores (dominated by smooth-walled d Cerebropollenites macroverrucosus (Thiergart) Schulz (5). e Perinopollenites elatoides Couper (1). f Araucariacites australis Cookson (1). g-h Monosulcites spp. (2, 2). i Classopollis spp. (1). j Podocarpidites spp. (2)

trilete forms) dominate in both marine and continental successions (Fig. 4, Table 1). The gymnosperm representation is also similar, dominated by bisaccate pollen produced by conifers and with the pollen Quadraeculina annelaeformis, Podozamites sp. and Eucommiidites troedssonii as subsidiary elements. A difference, however, is that while lycopsid spores are rare within the Bathonian assemblages of northwestern 
Donbas, lycopsids are abundant in successions within the Dnieper-Donets depression where they are represented by the genera Retitriletes, Selaginella and Leptolepidites.

The Kamyanski palynofloras constitute a typical Middle Jurassic spore-pollen association and share major aspects with Middle Jurassic assemblages from Europe, e.g. the UK North Sea (e.g. Slater et al. 2017), Yorkshire (Couper 1958; Slater and Wellman 2015, 2016; Slater et al. 2018b, this issue) and Poland (Ziaja 2006). The Ukrainian Middle Jurassic flora is also similar to coeval assemblages from Sweden (Tralau 1967, 1968; Guy-Ohlson 1971, 1986; Vajda 2001) and Denmark (Dybkjær 1988; Mehlqvist et al. 2009). Specifically, these assemblages are typically composed of abundant fern spores, often dominated by Cyathidites/Deltoidospora spp., abundant conifer pollen, often dominated by Cheirolepidiaceae (Classopollis spp.), Cupressaceae (e.g. Perinopollenites elatoides) and Araucariaceae pollen (e.g. Araucariacites australis and Callialasporites spp.) and bisaccate pollen produced from a mixture of conifers (e.g. Pinuspollenites spp.) and seed ferns (e.g. Alisporites spp.).

The high compositional similarity of spore-pollen assemblages from Middle Jurassic deposits across Europe suggests that floral provincialism was relatively limited. Interestingly, a similar pattern has been recognised from the Bathonian vertebrate faunas of Europe and Western Siberia (Skutschas 2016). This indicates that extensive, homogenous warm-temperate to sub-tropical ecosystems extended across Europe during the Middle Jurassic.

\section{Comparison between the palynoflora and macroflora}

The macroflora at the base of the claystone within subsuite 2 is considered to be in situ representing a fair record of the local vegetation. Diversity is lower in the topmost part of the exposure (Fig. 2) mainly due to a decrease in cycadophyte abundance and diversity. Before the onset of the Callovian marine transgression, cycadophyte abundances continued to decrease during the Bathonian of Ukraine and were replaced by conifers and, to a lesser extent, ginkgophytes (including Czekanowskia) and ferns (e.g. Cladophlebis, Coniopteris and Sphenopteris) (Stanislavskyi 1957a).

Comparison of the miospore and macrofloral assemblages importantly shows that the palynoflora and macroflora are highly similar at broad taxonomic levels; however, discrepancies that are more substantial are apparent at generic and species levels. Groups such as Ginkgoaceae and the fern family Ophioglossaceae are far better represented in the macroflora, primarily owing to the poor recognition of such groups in the miospore record. For example, ferns belonging to Coniopteris are easily recognised and highly diverse in the macrofloral record of Kamyanka, whereas dispersed Coniopteris spores are typically smooth trilete spores, comparable to Cyathidites minor Couper (e.g. Cunlin et al. 2012). This dispersed spore taxon has been assigned to many fern groups (Balme 1995); therefore, the spores cannot be linked to specific parent plants with confidence and, as such, provide a poor record of parent plant abundance/ diversity changes through time. Further examples include the pollen produced by the conifers Pagiophyllum and Brachyphyllum (Araucariaceae and Cheirolepidiaceae) which are difficult to distinguish, and as such, the pollen of these groups are recorded within the dispersed genera of Araucariacites and Classopollis. Perhaps most significantly, groups such as the Cycadales, ginkgophytes, and Bennettitales are generally well represented in macrofloral records from the Jurassic (e.g. Spicer and Hill 1979; Pole 2001, 2009; Popa 2014; Pott and McLoughlin 2014; Vajda et al. 2017; McLoughlin et al. 2018, this issue). However, such groups typically produce simple monosulcate pollen (e.g. Monosulcites); thus, the pollen record of these groups in isolation provides a poor record of the parent vegetation (e.g. Slater and Wellman 2016); as such, pollen found as dispersed grains in isolation (i.e. without macrofloral assemblages) cannot be assigned to even broad botanical groups.

In other cases, the miospore assemblages provide a more complete record of vegetation diversity; for example, groups such as bryophytes, lycopsids and ferns such as Osmundaceae and Gleicheniaceae are only represented in the spore record. Similar findings from coeval deposits from the Jurassic of Yorkshire, UK (e.g. Slater et al. 2015), and Poland (Ziaja 2006) suggest that these patterns represent consistent ecologi$\mathrm{cal}$, taphonomic and recognition biases that act across different depositional environments.

\section{Summary}

Our study of the hitherto little-known Kamyanska palynoflora of eastern Ukraine provides information on Middle Jurassic palynofloras of the region. The successions are dated as Bathonian and sub-divided into two assemblages, A and B, based on marine molluscs and the macroflora. Over 50 miospore taxa were identified, and efforts were made to integrate the mainly Russian taxonomy with that of Western Europe. The presence of rich macrofloras through the succession allowed comparisons between the miospore assemblages and the previously described macroflora, showing that these are highly similar at broad taxonomic levels. The combined results from the macro- and miospore assemblages reveal a vegetation with a canopy of conifers, such as Cupressaceae and Brachyphyllum (possibly both Araucariaceae and Cheirolepidiaceae) with a ground cover mainly represented by ferns of the families Osmundaceae, Gleicheniaceae and 
Cyatheaceae. This implies that a similar vegetation extended from eastern Ukraine across most of western Europe at the time. Due to the importance of hydrocarbon production in the Dnieper-Donets Basin, the TAI was assessed, showing values ranging from 3 to 3.5 , i.e. liquid petroleum to wet gas phase.

Our study revealing well-preserved and diverse palynofloras in the Jurassic successions of the Dnieper-Donets Basin paves the way for further, more comprehensive studies on Ukrainian assemblages to assist the correlation and comparison between eastern and western European vegetation patterns during the phase of Pangean break-up.

Acknowledgements We thank Susanne Feist-Burkhardt and Mike Pole for their constructive reviews contributing to this paper. The authors acknowledge the Karazin Kharkiv National University, the host organisation of the 100th anniversary of V.P. Makrydin during which the samples were collected. This is a contribution to the UNESCO/IGCP project 632 , Continental Crises of the Jurassic: Major Extinction Events and Environmental Changes Within Lacustrine Ecosystems.

Funding information The authors further acknowledge the support of the Swedish Research Council (Research links, 2013-6702), for O.S. and V.V. and that of Lund University Carbon Centre (LUCCI) for S.S. and V.V.

\section{Compliance with ethical standards}

Conflict of interest The authors declare that they have no conflict of interest.

Open Access This article is distributed under the terms of the Creative Commons Attribution 4.0 International License (http:// creativecommons.org/licenses/by/4.0/), which permits unrestricted use, distribution, and reproduction in any medium, provided you give appropriate credit to the original author(s) and the source, provide a link to the Creative Commons license, and indicate if changes were made.

\section{References}

Aliev, M. M., Genkina, R. Z., Dubrovskaya, E. N., \& Nikishova, V. M. (1981). Jurassic continental deposits of the east of Central Asia (dating, stratification, correlation). Moscow: Science.

Balme, B. E. (1995). Fossil in situ spores and pollen grains: an annotated catalogue. Review of Palaeobotany and Palynology, 87, $81-323$.

Batten, D. (1996). Chapter 26B. Palynofacies and petroleum potential. In J. Jansonius, \& D. C. McGregor (Eds.), Palynology: principles and applications (Vol. 3, pp. 1065-1084). Dallas: American Association of Stratigraphic Palynologists Foundation.

Couper, R. A. (1958). British Mesozoic microspores and pollen grains. Palaeontographica Abteilung B, 103, 75-179.

Cunlin, X., Ming, W., Shiwei, C., Jian, M., \& Weidong, D. (2012). Study on characteristics of in situ spores of Coniopteris simplex in Middle Jurassic period, Yaojie, Gansu. Chinese Journal of Geology, 47, 211-220.

Dybkjær, K. (1988). Palynological zonation and stratigraphy of the Jurassic section in the Gassum no.1-borehole, Denmark. Geological Survey of Denmark (DGU) A, 21, 5-73.
Eichwald, E. (1865). Lethaea Rossica ou Paleontologie de la Russie. Stuttgart. 1865. Periode moyenne, t. II, partie1, 7-71.

Feist-Burkhardt, S. (1992). Palynological investigations in the Lower and Middle Jurassic of Switzerland, France and Germany: palynofacies and type of organic matter, dinoflagellate cyst morphology and stratigraphy. Ph.D. thesis. Universitè de Genève, Geneva.

Gozhik, P. F. (2013). Stratigraphy of the Upper Proterozoic and Phanerozoic of Ukraine, 1. Stratigraphy of the Upper Proterozoic, Paleozoic and Mesozoic of Ukraine. Kyiv: IGN NAS of Ukraine. Logos. 637 pp.

Grigoryev N. B. (1900). To the Jurassic flora of Kamenka of Izyumsky district, Kharkov province. News of the Geological Committee.

Guy-Ohlson, D. (1971). Palynological investigations in the Middle Jurassic of the Vilhelmsfält boring, southern Sweden. Publications from the Institutes of Mineralogy, Palaeontology and Quaternary Geology, University of Lund, 168, $104 \mathrm{pp}$.

Guy-Ohlson, D. (1986). Jurassic palynology of the Vilhelmsfält Bore No. 1, Scania, Sweden. Toarcian-Aalenian. Stockholm: Section of Palaeobotany, Swedish Museum of Natural History. 127 pp.

Ilyina, V. I. (1968). Comparative analysis of spore-pollen complexes of Jurassic deposits in the southern part of Western Siberia. Moscow: Science. Stratigraphic Code of Ukraine. - Kyiv, $66 \mathrm{pp.}$

Kabyshev, B., Krivchenkov, B., Stovba, S., \& Ziegler, P. A. (1998). Hydrocarbon habitat of the Dniepr-Donets depression. Marine and Petroleum Geology, 15, 177-190.

Kryshtofovich, A. N. (1917). Materials for the knowledge of the Jurassic flora of the Ussuri region. Western Society for the Study of the Amur Region, v. XVI.

Kryshtofovich, A. N., \& Prinada, V. D. (1934). The Mesozoic flora of the USSR. L.- M., Novosibirsk, ONTI, 1934. (In Russian).

Lapteva, A. M. (1967). Palynology and stratigraphic subdivision of the Jurassic sediments from the northwestern outskirts of the Donbas. Geological Magazine, 27, 19-26.

Lungershausen, L. F. (1941). Some features of the paleogeography of the Dnieper-Donetsk geosyncline in the upper Paleozoic and Mesozoic. Materials on the oil content of the Dnieper-Donets Basin. Kyiv: Publishing House of the Academy of Sciences of the Ukrainian SSR.

Lungershausen, L. F. (1942). Bajocian and Bathonian deposits of the Donetsk ridge. Reports of the Academy of Sciences of the SSSR, 34, 186-189.

McLoughlin, S., Pott, C., \& Sobbe, I. (2018). The diversity of Australian Mesozoic bennettitopsid reproductive organs. In S. Slater, E. Kustatscher, and V. Vajda (Eds.), Jurassic biodiversity and terrestrial environments. Palaeobiodiversity and Palaeoenvironments, 98(1). https://doi.org/10.1007/s12549-017-0286-z.

Mehlqvist, K., Vajda, V., \& Larsson, L. (2009). An assemblage of a Middle Jurassic flora from Bornholm, Denmark - a study of a historic collection at Lund University, Sweden. GFF, 131, 137-146.

Pole, M. S. (2001). Repeated flood events and fossil forests at Curio Bay (Middle Jurassic), New Zealand. Sedimentary Geology, 144, 223242.

Pole, M. (2009). Vegetation and climate of the New Zealand Jurassic. GFF, 131, 105-111.

Popa, M. E. (2014). Early Jurassic bennettitalean reproductive structures of Romania. In E. Kustatscher, L. W. van den Hoek Ostende, H. Kerp (Eds.), Green planet-400 million years of terrestrial floras. Papers in honour of JHA van Konijnenburgvan Cittert. Palaeobiodiversity and Palaeoenvironments (pp. 327-362), 94.

Pott, C., \& McLoughlin, S. (2014). Divaricate growth habit in Williamsoniaceae (Bennettitales): unravelling the ecology of a key Mesozoic plant group. In E. Kustatscher, L. W. van den Hoek Ostende, H. Kerp (Eds.), Green planet-400 million years of terrestrial floras. Papers in honour of JHA van Konijnenburg- 
van Cittert. Palaeobiodiversity and Palaeoenvironments (pp. 307-325), 94.

Rovnina, L. V. (1972). Stratigraphic subdivision of the continental deposits of the Triassic and Jurassic regions of the Northwest of the West Siberian Lowland. Moscow: Science.

Sachsenhofer, R. F., Privalov, V. A., \& Panova, E. A. (2012). Panova Basin evolution and coal geology of the Donets Basin (Ukraine, Russia): an overview. International Journal of Coal Geology, 89, 26-40.

Semenova, E. V. (1970). Spores and pollen of the Jurassic deposits and the boundary layers of the Triassic of the Donbas. Kyiv: Scientific Opinion.

Shevchuk, O. A. (2007). New palynological data confirming the Middle Jurassic age of the deposits of the southern slope of the DnieperDonets depression. Paleontological Collection, 39, 56-65.

Shevchuk, O., \& Vajda, V. (2016). Stratigraphy and paleoecology of Middle Jurassic dinocyst assemblages from the Dnieper-Donets Basin of central Ukraine. 35th International Geological Congress. Cape Town: Paper 5193.

Shramkova, G. V. (1963). Spore-pollen complexes of the Mesozoic deposits of the north-western Donbass and the Dnieper-Donets Basin. Proceedings of the Voronezh University. Geological collection, 62, 93-98.

Shramkova, G. V. (1970). Spore-pollen complexes of the Jurassic and lower cretaceous of the Voronezh anticline and their stratigraphic significance. Voronezh: Publishing House of Voronezh University.

Skutschas, P. P. (2016). A new crown-group salamander from the Middle Jurassic of Western Siberia, Russia. In J. D. Gardner, \& T. Přikryl (Eds.), Contributions in honour of Zbyněk Roček. Palaeobiodiversity and Palaeoenvironments, 96(1), 41-48.

Slater, S. M., \& Wellman, C. H. (2015). A quantitative comparison of dispersed spore/pollen and plant megafossil assemblages from a Middle Jurassic plant bed from Yorkshire, UK. Paleobiology, 41, 640-660.

Slater, S. M., \& Wellman, C. H. (2016). Middle Jurassic vegetation dynamics based on quantitative analysis of spore/pollen assemblages from the Ravenscar Group, North Yorkshire, UK. Palaeontology, 59, 305-328.

Slater, S. M., Taylor, W. A., Batten, D. J., Hill, C. R., \& Wellman, C. H. (2015). Morphology and wall ultrastructure of a new and highly distinctive megaspore from the Middle Jurassic of Yorkshire, UK. Review of Palaeobotany \& Palynology, 216, 33-43.

Slater, S. M., McKie, T., Vieira, M., Wellman, C. H., \& Vajda, V. (2017). Episodic river flooding events revealed by palynological assemblages in Jurassic deposits of the Brent Group, North Sea. Palaeogeography, Palaeoclimatology, Palaeoecology, 485, 389400.

Slater, S., Kustatscher, E., \&Vajda, V. (2018a). An introduction to Jurassic biodiversity and terrestrial environments. In S. Slater, E. Kustatscher, and V. Vajda (Eds.), Jurassic biodiversity and terrestrial environments. Palaeobiodiversity and Palaeoenvironments, 98(1). https://doi.org/10.1007/s12549-017-0316-x.

Slater, S. M., Wellman, C. H., Romano, M., \& Vajda, V. (2018b). Dinosaurplant interactions within a Middle Jurassic ecosystem - palynology of the Burniston Bay dinosaur footprint locality, Yorkshire, UK. In S. Slater, E. Kustatscher, and V. Vajda (Eds.), Jurassic biodiversity and terrestrial environments. Palaeobiodiversity and Palaeoenvironments, 98(1). https://doi.org/10.1007/s12549-017-0309-9.
Spicer, R. A., \& Hill, C. R. (1979). Principal components and correspondence analyses of quantitative data from a Jurassic plant bed. Review of Palaeobotany \& Palynology, 28, 273-299.

Stanislavskyi, F. A. (1953). Upper Triassic and Jurassic flora of the Great Donbass. Geological Journal of the Academy of Sciences of the USSR, 13, 59-65.

Stanislavskyi, F. A. (1957a). Jurassic Flora of the Don Basin and DnieperDonetz region. The Academy of Sciences of Ukraine, Kiev, 1-128.

Stanislavskyi, F. A. (1957b). Fossil flora of Bathonian-Callovian deposits of the Donetsk Basin and the Dnieper-Donets Basin. Kyiv: Abstract volume, 129

Stanislavskyi, F. A. (1964). About the age of sediments with plant fossils from the Middle to Upper Jurassic boundary of the Great Donbass. Geological Journal of the Academy of Sciences of the USSR, 24, 101-104.

Stanislavskyi, F. A. (1965). Age of continental coal deposits of the northern margin of the Ukrainian Shield. Geological Magazine, 25, 95-98.

Steinthorsdottir, M., \& Vajda, V. (2015). Early Jurassic (late Pliensbachian) $\mathrm{CO}_{2}$ concentrations based on stomatal analysis of fossil conifer leaves from eastern Australia. Gondwana Research, 27, 932-939.

Stovba, S. M., Maystrenko, P., Stephenson, R. A., \& Kusznir, N. J. (2003). The formation of the south-eastern part of the DnieprDonets Basin: 2-D forward and reverse modelling taking into account post-rift redeposition of syn-rift salt. Sedimentary Geology, $156,11-33$.

Thomas, T. T. (1911). The Jurassic Flora of Kamenka in the district of Isium, memoirs com. Geology Saint Petersburg, 71, 1-95.

Tralau, H. (1967). Some Middle Jurassic microspores of southern Sweden. Geologisca Foreningens i Stockholm Förhandlingar, 89, 469-472.

Tralau, H. (1968). Botanical investigation into the fossil flora of Eriksdal in Fyledalen, Scania. II. The Middle Jurassic microflora. Sveriges Geologiska Undersökning Series C, 633, 1-185.

Vajda, V. (2001). Aalenian to Cenomanian palynofloras of SW Scania, Sweden. Acta Paleontologica Polonica, 46, 403-426.

Vajda, V., \& Wigforss-Lange, J. (2009). Onshore Jurassic of Scandinavia and related areas. $G F F, 131,5-23$.

Vajda, V., Pucetaite, M., McLoughlin, S., Engdahl, A., Heimdal, J., \& Uvdal, P. (2017). Molecular signatures of fossil leaves provide unexpected new evidence for extinct plant relationships. Nature Ecology \& Evolution. https://oi.org/10.1038/s41559-017-0224-5.

Van Hinsbergen, D. J. J., Abels, H. A., Bosch, W., Boekhout, F., Kitchka, A., Hamers, M., van der Meer, D. G., Geluk, M., \& Stephenson, R. A. (2015). Sedimentary geology of the middle Carboniferous of the Donbas region (Dnieper-Donets Basin, Ukraine). Scientific Reports, 5(9099), 1-8. https://doi.org/10. 1038/srep09099.

Yamnichenko, L. M. (1969). Stratigraphy of the USSR, Jurassic, 7. Kyiv. Science Opinion. 216 pp.

Yanovskaya, G. G. (1986). Palynozones Jurassic deposits Pre-Dobrogea trough. Biostratigraphy of oil and gas bearing areas of the Soviet Union. Materials $V$ of the Interdepartmental Stratigraphic Conference. Baku, Azerbaijan: Abstract volume, 182-183.

Ziaja, J. (2006). Lower Jurassic spores and pollen grains from Odrowąż, Mesozoic margin of the Holy Cross Mountains, Poland. Acta Palaeobotanica, 46, 3-83. 